\title{
ArcheoSciences
}

Revue d'archéométrie

\section{Thracian golden wreath from Kabyle, Bulgaria: chemical composition}

Thracian couronne d'or de Kabyle, Bulgarie: composition chimique

Deyan Lesigyarski, Boika Zlateva, Valentina Lyubomirova, Totko Stoyanov and Ivelin Kuleff

\section{(2) OpenEdition}

12 Journals

\section{Electronic version}

URL: https://journals.openedition.org/archeosciences/4440

DOI: 10.4000/archeosciences. 4440

ISBN: 978-2-7535-4778-0

ISSN: 2104-3728

Publisher

Presses universitaires de Rennes

\section{Printed version}

Date of publication: 31 December 2015

Number of pages: 149-156

ISBN: 978-2-7535-4776-6

ISSN: 1960-1360

\section{Electronic reference}

Deyan Lesigyarski, Boika Zlateva, Valentina Lyubomirova, Totko Stoyanov and Ivelin Kuleff, "Thracian golden wreath from Kabyle, Bulgaria: chemical composition", ArcheoSciences [Online], 39 | 2015, Online since 31 December 2017, connection on 28 January 2022. URL: http://journals.openedition.org/ archeosciences/4440 ; DOI: https://doi.org/10.4000/archeosciences.4440 


\title{
Thracian Golden Wreath from Kabyle, Bulgaria: Chemical Composition
}

\author{
Couronne d'or thrace de Kabyle, Bulgarie : composition chimique
}

\author{
Deyan Lesigyarskia, Boika Zlateva a, Valentina Lyubomirova ${ }^{a}$, \\ Totko Stoyanov ${ }^{b}$ and Ivelin KulefF ${ }^{a}$
}

\begin{abstract}
The chemical composition of a Thracian gold wreath from Kabyle dated to $4^{\text {th }}$ century BC (Thracian age in Bulgaria) was analyzed. $\mathrm{Au}, \mathrm{Ag}$ and $\mathrm{Cu}$ concentrations were determined by inductively coupled plasma-atomic emission spectrometry (ICP-AES) while As, Bi, Cd, Co, Fe, Zn, Sn, Sb, Ga, In, Mn, Mo, Ni, Pb, PGEs (Pt, Pd, Ir, Re, Rh, Ru), Se, Te, Ti, U, W, Zn, and Zr concentrations - by inductively coupled plasma-mass spectrometry (ICP-MS). Data showed that the wreath was made of very well purified gold alloy (Au content between 97.1 and 99.9\%). The bivariate plot of the Pd and Pt concentrations showed that the gold used for these artefacts came from four different sources. Due to the lack of analytical data about the platinum group elemental (PGEs) concentrations from different gold sources in Bulgaria it was impossible at this stage to identify the geographical location of the four sources for the gold wreath.

Résumé : La composition chimique de la couronne d'or thrace provenant de Kabyle, daté du Iv siècle av. J.-C. (second Âge du Fer) a été déterminée. Les concentrations en $A u, A g$ et Cu a été établit par spectrométrie d'émission atomique couplée à une torche plasma (ICP-AES) et les teneurs en As, Bi, Cd, CO, $\mathrm{Fe}, \mathrm{Zn}, \mathrm{Sn}, \mathrm{Sb}, \mathrm{Ga}, \mathrm{In}, \mathrm{Mn}, \mathrm{Mo}, \mathrm{Ni}, \mathrm{Pb}, \mathrm{PGEs}$ (Pt, Pd, Ir, Re, Rh, Ru), Se, Te, Ti, U, W, Zn et Zr par spectrométrie de masse couplée à un plasma inductif (ICP-MS). Les données ont montré que la couronne a été réalisée avec un alliage d'or assez pure (Au entre 97,1 et 99,9\%). Le rapport entre les concentrations en Pd et en Pt a montré que l'or utilisé pour la fabrication de cet objet provient de quatre sources différentes. À cause du manque de données analitiques disponibles sur les concentration en PGEs dans les différents sources d'or de Bulgarie, il a été impossible à ce stade d'identifier leur location géographique.
\end{abstract}

Keywords: Thracian gold wreath, Kabyle, Bulgaria, ICP-AES, ICP-MS.

Mots clés: Couronne d'or de Thrace, Kabyle, Bulgarie, ICP-AES, ICP-MS.

\section{INTRODUCTION}

The remains of the ancient town of Kabyle are situated on the eastern edge of the Zaychi vrah hill, near the big elbow of Tundzha River, ancient Tonzos River. Map of Bulgaria with the position of the ancient (respectively modern) settlement of Kabyle is presented in Figure 1. This settlement, which was one of the most important Thracian towns, was reorganized by Philip II of Macedonia becoming a strategic and economic center of that area after his conquest of South-Eastern
Thrace in 342-341 BC (Domaradski and Taneva, 1998; Popov, 2002). Later, in 72 BC Kabyle was conquered by the Roman general Marcus Lucullus (Velkov, 1990). During the $2^{\text {nd }}$ century AD the Kabyle fortress served as residence of the Cohors II Lucensium, and in the next century of the Cohors I Athoitorum. Therefore Kabyle was one of the two main Roman camps in the province of Thracia (Getov, 2003).

The gold samples from Kabyle were collected from the "Big tumulus", located between the modern village of Kabyle and the remains of the ancient settlement. The "Big

\footnotetext{
a Faculty of Chemistry and Pharmacy, University of Sofia, 1, James Bourchier blvd., 1164-Sofia, Bulgaria.

b Faculty of History, University of Sofia, 15, Tsar Osvoboditel blvd., 1504-Sofia, Bulgaria.
} 


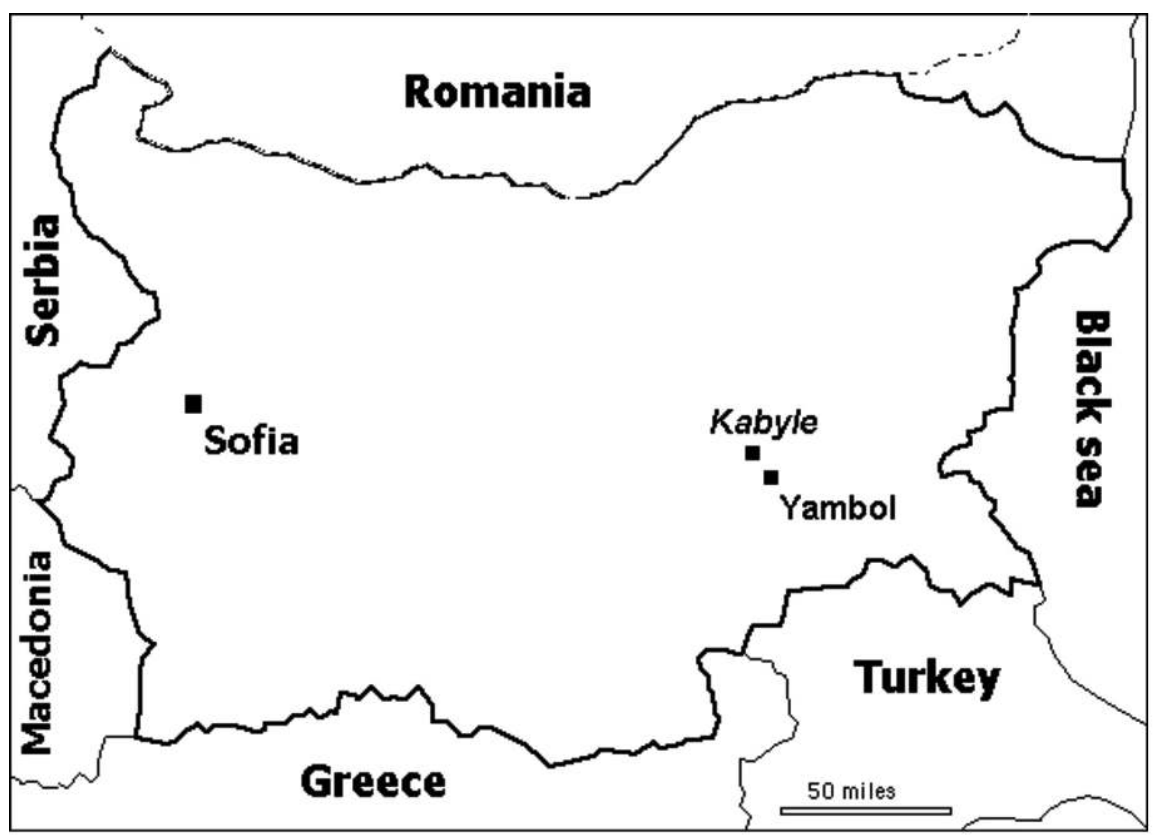

Figure 1: Map of Bulgaria where the position of the ancient settlement of Kabyle is shown.

Figure 1: Carte de la Bulgarie montrant la localisation de la ville ancienne de Kabyle. tumulus" was about $8 \mathrm{~m}$ in height and $40-45 \mathrm{~m}$ in diameter. In the north-eastern part of the tumulus a pyre-grave was excavated. The body laid along with his personal belongings, arms and imported vessels (Stoyanov et al., 2010). The funeral could be dated to the last third of the $4^{\text {th }}$ century BC. It was assumed that a military officer of the ancient fortress was buried there (Stoyanov et al., 2010; 2013).

The arms, found in the grave, consist of a sword, many iron spear heads and butts intended for long thrusting spears and javelins. Besides, a bronze horse-bit, which was torn to pieces before being placed under the funeral pyre, was found (Stoyanov et al., 2010; 2013). After Donder, the horse-bit belongs to type VII (cat. Nr. 74-78, Taf. 9) (Donder, 1980), known from excavated finds in Olynthus, Thebes, Dodona and Peloponnesus. Two finds were discovered at Starosel and Dolna Koznitsa in Southern Thrace (modern South-Eastern Bulgaria). Among the remains of the funeral pyre many parts of a bronze wreath, cut into pieces and dispersed all over the fireplace were discovered. The wreath consisted of gilded bronze leafs and gilded clay beads of different forms, as well as large quantities of bronze beads (Stoyanov et al., 2013). Among the remains of the funeral pyre also a twig from a second wreath made of gold, as well as small thin sheets or other gold artifacts were discovered (Stoyanov et al., 2010; 2013). The gold samples investigated in the present study come from the above group of finds.

Despite the relatively large number in Bulgaria of golden artifacts dated to the Thracian period, their analytical study are very rare (e.g. Kuleff et al., 2009). Archaeometric investigations of this period are also scarce in other contries (see e.g. Gondonneau et al., 2001; Guerra, 2004; 2005, 2008; Guerra and Calligaro, 2007; Iliev, 2006; Junk and Pernicka, 2003, Schlosser et al., 2009).

In the present work the analytical data obtained for the gold finds from the pyre-grave in the "Big tumulus" near Kabyle are reported. The analyses were carried out by ICPAES (inductively coupled plasma-atomic emission spectroscopy) and ICP-MS (inductively coupled plasma-mass spectrometry). The aim of this investigation is to identify the gold sources by determination of large number of elements, including microcomponents. Moreover, due to the lack of literature data, the results obtained in this study will be a good base for comparison in future investigations.

\section{Materials AND METHODS}

\section{Materials}

For the purpose of this study ten gold samples were analyzed. Their brief description with respect to the archaeological context is reported in Table 1 while in Figure 2 pictures of several samples are shown. Since the buried man was initially cremated on a wooden construction of $4 \times 4 \mathrm{~m}$, made in several levels, the grave inventory was exposed to very high temperatures, traceable on some of the gold pieces (Stoyanov et al., 2013). 


\begin{tabular}{|l|l|}
\hline Nr. & Description \\
\hline 3000.KAB & Village of Kabyle, Big tumulus, north-eastern part - funeral-pile; golden foil; weight 0.302 g \\
\hline 300la.KAB & $\begin{array}{l}\text { Village of Kabyle, Big tumulus, north-eastern part - funeral-pile; smelted leaf and fruits from golden wreath; weight } 0.333 \mathrm{~g} \\
\text { (sample from the leaf) }\end{array}$ \\
\hline 300lb.KAB & $\begin{array}{l}\text { Village of Kabyle, Big tumulus, north-eastern part - funeral-pile; smelted leaf and fruits from golden wreath; weight } 0.333 \mathrm{~g} \\
\text { (sample from the stalk) }\end{array}$ \\
\hline 3002a.KAB & Village of Kabyle, Big tumulus, north-eastern part - funeral-pile; golden beads from wreath; weight $0.422 \mathrm{~g}$ (sample from stalk) \\
\hline 3002b.KAB & Village of Kabyle, Big tumulus, north-eastern part - funeral-pile; golden beads from wreath; weight $0.422 \mathrm{~g}$ (sample from acorn) \\
\hline 3003.KAB & Village of Kabyle, Big tumulus, north-eastern part - funeral-pile; golden foil; weight $0.189 \mathrm{~g}$ \\
\hline 3004.KAB & Village of Kabyle, Big tumulus, north-eastern part - funeral-pile; smelted fruit from golden wreath; weight $0.473 \mathrm{~g}$ \\
\hline 3005.KAB & Village of Kabyle, Big tumulus, north-eastern part - funeral-pile; golden foil; weight $0.402 \mathrm{~g}$ \\
\hline 3006.KAB & Village of Kabyle, Big tumulus, north-eastern part - funeral-pile; golden foil; weight $0.135 \mathrm{~g}$ \\
\hline 3007.KAB & $\begin{array}{l}\text { Village of Kabyle, Big tumulus, north-eastern part - funeral-pile; golden foil and covered with golden foil clay bead; weight } \\
\text { 0.272 g }\end{array}$ \\
\hline 3008.KAB & Village of Kabyle, Big tumulus, north-eastern part - funeral-pile; golden foil - smelted in the periphery leaf; weight $0.200 \mathrm{~g}$ \\
\hline 3009.KAB & Village of Kabyle, Big tumulus, north-eastern part - funeral-pile; golden foil; weight $0.533 \mathrm{~g}$ \\
\hline
\end{tabular}

Table 1: Description of the analyzed gold samples from the grave-tumulus near the ancient town of Kabyle. Tableau 1 : Description des échantillons d'or analysés provenant des tumulus situés autour de la ville ancienne de Kabyle.

Figure 2: (see colour plate X) Pictures of some of the analysed gold-samples.

Figure 2 : (voir planche couleur $X)$ Photographies de quelques échantillons d'or étudiés.

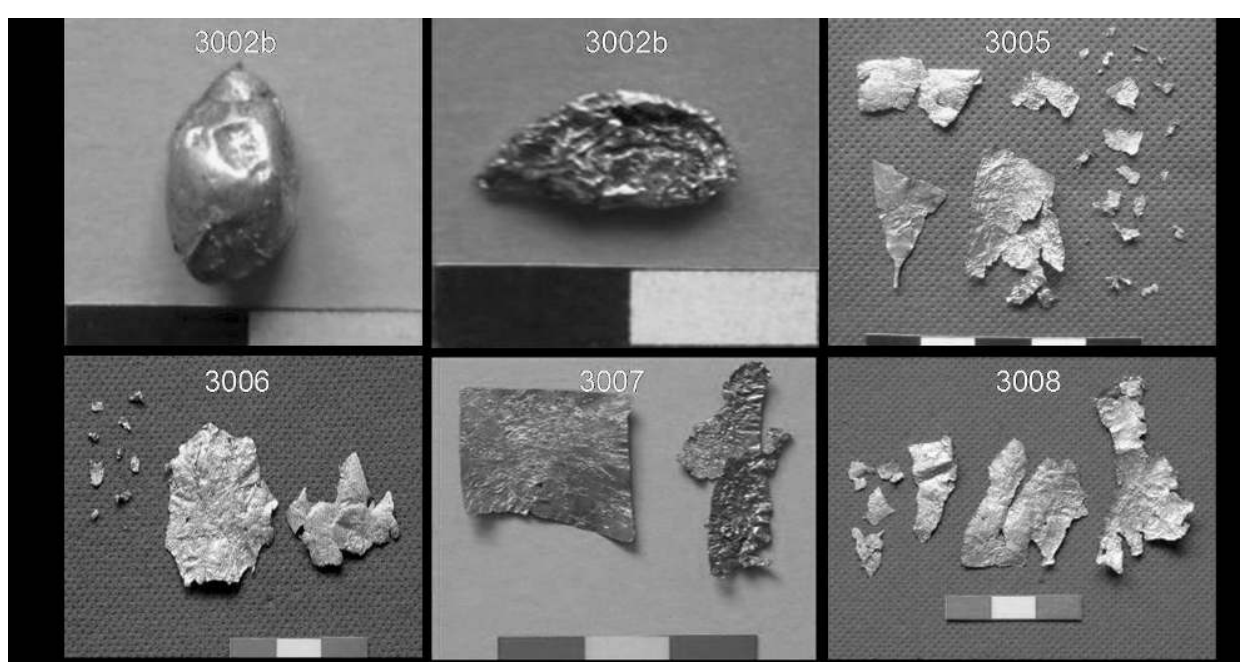

\section{Methods of analysis}

For the determination of the major elements $\mathrm{Au}, \mathrm{Ag}$ and Cu ICP-AES (Perkin Elmer's Optima 7000 DV) was used. The determination of microcomponents was performed by ICP-MS (Perkin Elmer SCIEX DRC-e system). The concentrations of the following 27 elements were determined (in $\left.\mathrm{mg} \mathrm{kg}^{-1}\right)$ : As, Bi, Cd, Co, Fe, Ga, Hg, In, Ir, Mn, Mo, Ni, $\mathrm{Pb}, \mathrm{Pd}, \mathrm{Pt}, \mathrm{Re}, \mathrm{Rh}, \mathrm{Ru}, \mathrm{Sb}, \mathrm{Se}, \mathrm{Sn}, \mathrm{Te}, \mathrm{Ti}, \mathrm{U}, \mathrm{W}, \mathrm{Zn}, \mathrm{Zr}$. The weight of each sample was about $5 \mathrm{mg}$, samples were digested in $3 \mathrm{~mL}$ aqua regia $\left(\mathrm{HNO}_{3}: \mathrm{HCl}=1: 3\right)$ and after that diluted to volume of $20 \mathrm{~mL}$ with double deionized water. For ICP-MS determination additionally $1 \mathrm{~mL}$ was diluted to $10 \mathrm{~mL}$ with double deionized water.
The formation of $\mathrm{AgCl}$ deposit was carefully controlled. In this case additionally $1 \mathrm{~mL}$ concentrated $\mathrm{HCl}$ was added to the digested samples.

Suprapur chemicals and double deionized water (MilliQ) were used for preparing all solutions. Working matrix-matched standard solutions were prepared from single standard solutions (Merck GmbH, Germany) with initial concentration $1000 \mathrm{mg} \mathrm{mL}^{-1}$ by appropriate dilution.

The validation of the methods was performed analyzing the standard reference materials Gold NA-Au-30 and NA-Au-31 (Aurubis AG, Germany). The results are presented in Table 2. 


\begin{tabular}{|c|c|c|c|c|}
\cline { 2 - 5 } \multicolumn{1}{c|}{} & \multicolumn{2}{|c|}{ NA-Au-30 } & Experimental value & Certified value \\
\hline Element & Experimental value & Certified value & $5.49 \pm 0.44$ & 5.45 \\
\hline $\mathrm{Ag}$ & $1.01 \pm 0.07$ & 1.00 & $1075 \pm 68$ & 1062 \\
\hline $\mathrm{Cu}$ & $102 \pm 5$ & 99 & $108 \pm 10$ & 112 \\
\hline $\mathrm{As}$ & $41 \pm 4$ & 43 & $106 \pm 7$ & 100 \\
\hline $\mathrm{Bi}$ & $10.0 \pm 0.6$ & 9 & $118 \pm 20$ & 82 \\
\hline $\mathrm{Cd}$ & $8.0 \pm 0.4$ & 10 & $796 \pm 76$ & 124 \\
\hline $\mathrm{Co}$ & $9 \pm 2$ & 34 & $60 \pm 5$ & 606 \\
\hline $\mathrm{Fe}$ & $32 \pm 2$ & 7 & $1100 \pm 45$ & 1092 \\
\hline $\mathrm{Mn}$ & $8.0 \pm 0.2$ & 48 & $1103 \pm 36$ & 90 \\
\hline $\mathrm{Ni}$ & $51 \pm 2$ & 9 & $1140 \pm 29$ & 112 \\
\hline $\mathrm{Pb}$ & $10.0 \pm 0.4$ & 55 & $110 \pm 6$ & 1152 \\
\hline $\mathrm{Pd}$ & $58 \pm 2$ & 58 & $125 \pm 16$ & 102 \\
\hline $\mathrm{Pt}$ & $56 \pm 1$ & 9 & $760 \pm 32$ & 114 \\
\hline $\mathrm{Sb}$ & $10.0 \pm 0.5$ & 10 & $120 \pm 11$ & 772 \\
\hline $\mathrm{Se}$ & $12 \pm 1$ & 50 & $110 \pm 5$ & 112 \\
\hline $\mathrm{Sn}$ & $47 \pm 2$ & $11 \pm 1$ & 114 & \\
\hline $\mathrm{Te}$ & $10.0 \pm 0.3$ & & & \\
\hline $\mathrm{Zn}$ & & 10 & & \\
\hline
\end{tabular}

Table 2: Experimental and certified values for $\mathrm{Ag}(\%)$ and other 16 elements ( $\left.\mathrm{mg} \mathrm{kg}^{-1}\right)$ in SRMs NA-Au-30 and NA-Au-31.

Tableau $2:$ Les valeurs expérimentales et certifiés pour $\mathrm{Ag}(\%)$ et 16 autres éléments ( $m g \mathrm{~kg}^{-1}$ ) dans SRM NA-Au-30 et NA-Au-31.

\section{Results AND DisCUSSIONS}

The results obtained by the analysis of gold samples from the pyre-grave in the "Big tumulus" near Kabyle are reported in Table 3, where the concentrations of the major components ( $\mathrm{Au}, \mathrm{Ag}$, and $\mathrm{Cu}$ ) are shown in weight $\%$, while those of the micro components are in $\mathrm{mg} \mathrm{kg}^{-1}$.

Copper and silver are the major metallic impurities in native gold and most gold ores (Boyle, 1987; Hall et al., 1998; Pohl, 1992). In general, the silver concentration in ancient gold objects from Europe is within 4 to $45 \%$ (Hauptmann et al., 2010; Kuleff et al., 2009; Pantazis et al., 2003) with the most common concentrations of about 12-14\% Ag (Hauptmann et al., 2010; Pantazis et al., 2003). The values for copper are within 0.5 and $15 \%$ (Hauptmann et al., 2010; Pantazis et al., 2003). Such chemical composition indicates the presence of a gold alloy containing a significant part of impurities. The results presented in Table III show different concentration intervals of the macrocomponents in the studied samples. Gold concentration between 97.1 and $99.9 \%$ is an indication that the analyzed samples were made of very pure gold alloy which could be obtained after careful purification of natural gold, most probably through cementation process (Ramage and Craddock,
2000). The relatively low silver and copper concentrations (between $0.07-2.3 \%$ and $0.005-0.8 \%$ respectively) support this conclusion. Considering that a carat is a $1 / 24$ part of pure metal content in the alloy (when talking about gold and platinum alloys), it follows that the analyzed gold from Kabyle has purity of 23.31 to 23.98 carats (respectively from 970 to 998 in fineness). In comparison, the most common commercial forms of gold nowadays -14 and 18 carats, are characterized by gold percentage between 58 and 75\%. The low levels of the other measured elements (Table 3) once again lead to the assumption that the gold from Kabyle was carefully purified during the manufacturing process (Ramage and Craddock, 2000). However, the uncertainties of some of the elemental concentrations (see Table 3) indicate inhomogeneity of the material. For example, the iron concentration in the samples varied from 256 to $3396 \mathrm{mg}$ $\mathrm{kg}^{-1}$, that of platinum -43 to $129 \mathrm{mg} \mathrm{kg}^{-1}$ and of palladium is in the range from 15 to $109 \mathrm{mg} \mathrm{kg}^{-1}$, etc. Such results can be explained with the very likely partial smelting of the gold pieces from the wreath during the incineration.

It is believed that concentrations of copper in ancient gold artifacts exceeding 3\% are clear indication for alloying gold, possibly aiming to reduce its cost, while alloys with less than $1 \%$ copper are naturally occuring. Alloys with $1-3 \%$ copper could be natural or human made (Hall et al., 1998). The $\mathrm{Cu}$ concentrations in the analyzed findings are, however, too low - less than $0.8 \%$, so most probably a very pure gold alloy was used, most likely obtained after careful purification of natural gold (Ramage and Craddock, 2000). 
It is well known that in alluvial deposits, gold can be associated with cassiterite $\left(\mathrm{SnO}_{2}\right)$, iron hydroxide $\left(\mathrm{Fe}(\mathrm{OH})_{3}\right)$ and the platinum group elements (PGEs). Gold ores in reef or lode deposits are often associated with quartzite and other metallic minerals such as arsenopyrite (FeAsS), chalcopyrite $\left(\mathrm{CuFeS}_{2}\right)$, galena $(\mathrm{PbS})$, sphalerite $((\mathrm{Zn}, \mathrm{Fe}) \mathrm{S})$, tellurides and tetrahedrite (Hall et al., 1998). The presence of traces of $\mathrm{Sn}$ in the studied objects is characteristic of alluvial gold, probably due to riverbed cassiterite and the absence of $\mathrm{Sn}$ is a sign for other gold sources: mine or refined gold (Kuleff, 2012; Ramage and Craddock, 2000; Vasilescu et al., 2011). Extremely low Te and Sb were found, but being volatile elements, the refining technology might eliminate them (Ramage and Craddock, 2000). High concentration of iron was also measured in the gold samples. Considering that iron objects were found in the grave (Stoyanov et al., 2013) which might have been in contact with the gold samples could be accepted as a reason for its high concentration and its difference between the samples. It can also be due to the long stay of the samples in the soil. Since iron is a component of common gangue minerals, it does not reflect the geographic provenance of the gold (Vasilescu et al., 2011).

Regarding the small number of analyses of gold artifacts from the same historical period in Bulgaria, comparison with other results appears to be difficult. The wreath from Kabyle is dated to the same period with several golden breastplates from Southern Thrace (see Kuleff et al., 2009) - about $4^{\text {th }}$ century BC. However, in contrast to the Kabyle wreath, the breastplates were most likely produced of natural (not purified) gold. For example, the results obtained by analyses of natural (alluvial) gold from the region (Cojocaru et al., 2003; Kovachev et al., 2007; Stefanova et al., 2007) are in very good accordance with those from the breastplates and they show relatively high silver and copper concentrations, higher than those measured in the samples from Kabyle.

Usually concentration ratios between elements of the platinum group can represent the similarity between the sources of natural gold and the gold that was used for production of the studied artifacts. It is very obvious to assume that the ancient goldsmiths have used only one source of natural gold to make an object. In the Classical and Hellenistic periods when gold was purified probably different sources might have been used.

In Figure 3 the distribution of the analyzed gold samples according to the concentrations of platinum and palladium is presented. The grouping of the samples shows that at least four sources of gold were used by the ancient goldsmiths. The scatterplot in Figure 4 presents the distribution of the samples according the ratios of $\mathrm{Ag} / \mathrm{Au}$ and $\mathrm{Pd} / \mathrm{Pt}$. Considering the grouping of the samples in both bivariate plots the assumption of four sources of gold could be accepted. Samples 3006.KAB, 3007.KAB and 3008.KAB are grouped together in both scatterplots.

Additionally the samples 3003.KAB and 3005.KAB forming a group in Figure 3 are separated from the other samples in Figure 4. Very close concentration values of other trace elements as $\mathrm{Sn}, \mathrm{Te}, \mathrm{Ti}, \mathrm{Zn}$ and $\mathrm{Zr}$ are also observed.

Furthermore, the similar concentrations of $\mathrm{Zn}$ and $\mathrm{Zr}$ (see Table 3) of the samples in the respective groups in Figure 3 could also be accepted as a confirmation of the above statement.

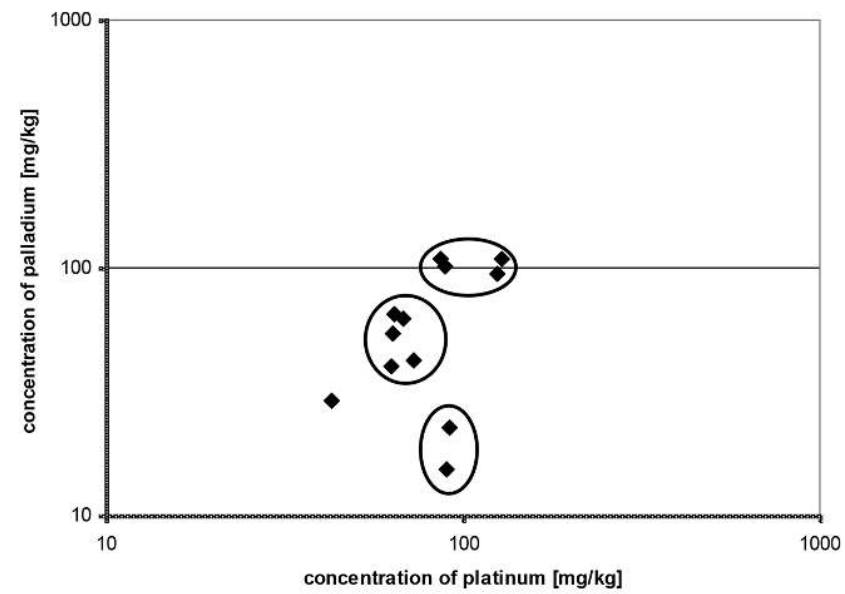

Figure 3: Correlation between the concentrations of platinum and palladium $\left(\mathrm{mg} \mathrm{kg}^{-1}\right)$.

Figure 3 : Correlation entre des concentrations en platine et en palladium $\left(\mathrm{mg} \mathrm{kg}^{-1}\right)$.

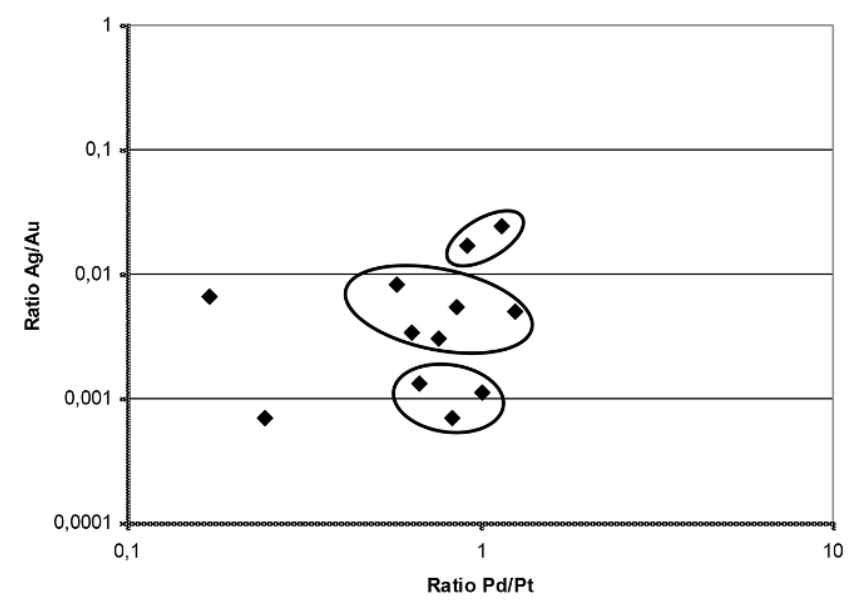

Figure 4: Distribution of the analyzed gold-samples according the $\mathrm{Pd} / \mathrm{Pt}$ and $\mathrm{Ag} / \mathrm{Au}$ ratios.

Figure 4 : Distribution des échantillons d'or analysés en fonction des raports Pd/Pt et $A g / A u$. 


\begin{tabular}{|c|c|c|c|c|c|c|}
\hline & Sample & & & & & \\
\hline El. & 3000.KAB & 3001a.KAB & 3001b.KAB & 3002a.KAB & 3002b.KAB & 3003.KAB \\
\hline $\mathrm{Au}[\%]$ & $98.16 \pm 0.73$ & $98.88 \pm 0.59$ & $97.11 \pm 0.73$ & $99.76 \pm 0.80$ & $99.67 \pm 0.70$ & $99.87 \pm 0.14$ \\
\hline $\mathrm{Ag}[\%]$ & $1.64 \pm 0.48$ & $0.49 \pm 0.10$ & $2.33 \pm 0.48$ & $0.11 \pm 0.03$ & $0.070 \pm 0.016$ & $0.070 \pm 0.018$ \\
\hline $\mathrm{Cu}[\%]$ & $0.15 \pm 0.05$ & $0.09 \pm 0.03$ & $0.79 \pm 0.04$ & $0.20 \pm 0.04$ & $0.005 \pm 0.002$ & $0.029 \pm 0.009$ \\
\hline As & $89.30 \pm 20.2$ & $48.3 \pm 8.7$ & $60.5 \pm 20.2$ & $84.3 \pm 8.7$ & $218 \pm 27$ & $147 \pm 29$ \\
\hline $\mathrm{Bi}$ & $0.67 \pm 0.24$ & $<0.003$ & $<0.003$ & $6.2 \pm 1.7$ & $8.9 \pm 1.6$ & $<0.003$ \\
\hline $\mathrm{Cd}$ & $2.93 \pm 0.45$ & $<0.01$ & $<0.01$ & $10.3 \pm 2.6$ & $23.3 \pm 6.5$ & $0.046 \pm 0.019$ \\
\hline Co & $0.35 \pm 0.11$ & $0.60 \pm 0.16$ & $0.6 \pm 0.1$ & $0.60 \pm 0.16$ & $0.50 \pm 0.04$ & $9.4 \pm 1.4$ \\
\hline $\mathrm{Fe}$ & $256.3 \pm 46.1$ & $403 \pm 55$ & $458 \pm 46$ & $826 \pm 55$ & $772 \pm 27$ & $3396 \pm 183$ \\
\hline $\mathrm{Ga}$ & $<0.004$ & $<0.004$ & $<0.004$ & $0.4 \pm 0.1$ & $0.2 \pm 0.04$ & $3.0 \pm 0.5$ \\
\hline In & $0.22 \pm 0.08$ & $<0.003$ & $<0.003$ & $0.14 \pm 0.04$ & $0.3 \pm 0.1$ & $0.013 \pm 0.006$ \\
\hline Ir & $0.067 \pm 0.013$ & $0.50 \pm 0.08$ & $0.4 \pm 0.01$ & $0.30 \pm 0.08$ & $0.35 \pm 0.06$ & $1.2 \pm 0.3$ \\
\hline $\mathrm{Mn}$ & $15.2 \pm 5.0$ & $15.0 \pm 4.5$ & $25.4 \pm 5.0$ & $23.6 \pm 4.5$ & $43.0 \pm 8.3$ & $156 \pm 23$ \\
\hline Mo & $0.050 \pm 0.018$ & $0.15 \pm 0.05$ & $0.2 \pm 0.02$ & $<0.01$ & $0.14 \pm 0.06$ & $0.22 \pm 0.08$ \\
\hline $\mathrm{Ni}$ & $0.63 \pm 0.19$ & $1.5 \pm 0.3$ & $1.3 \pm 0.2$ & $<0.06$ & $<0.06$ & $2.3 \pm 0.7$ \\
\hline $\mathrm{Pb}$ & $759 \pm 114$ & $6.5 \pm 0.6$ & $5.7 \pm 0.9$ & $20.7 \pm 1.8$ & $23.2 \pm 4.8$ & $110 \pm 24.3$ \\
\hline $\mathrm{Pd}$ & $62.7 \pm 11.5$ & $109 \pm 7$ & $102 \pm 12$ & $65 \pm 6$ & $108 \pm 30$ & $22.7 \pm 4.5$ \\
\hline $\mathrm{Pt}$ & $67.9 \pm 6.7$ & $86.3 \pm 9.2$ & $88.8 \pm 6.7$ & $64 \pm 9$ & $129 \pm 30$ & $92 \pm 29$ \\
\hline $\operatorname{Re}$ & $<0.001$ & $<0.001$ & $<0.001$ & $<0.001$ & $<0.001$ & $<0.001$ \\
\hline $\mathrm{Rh}$ & $0.092 \pm 0.037$ & $0.19 \pm 0.02$ & $0.19 \pm 0.04$ & $0.028 \pm 0.008$ & $0.07 \pm 0.03$ & $0.30 \pm 0.09$ \\
\hline $\mathrm{Ru}$ & $<0.001$ & $<0.001$ & $0.04 \pm 0.01$ & $<0.001$ & $<0.001$ & $0.048 \pm 0.019$ \\
\hline $\mathrm{Sb}$ & $0.067 \pm 0.032$ & $<0.003$ & $<0.003$ & $<0.003$ & $<0.003$ & $1.5 \pm 0.5$ \\
\hline $\mathrm{Se}$ & $<0.3$ & $<0.3$ & $<0.3$ & $<0.3$ & $<0.3$ & $<0.3$ \\
\hline Sn & $6.0 \pm 2.1$ & $8.2 \pm 3.0$ & $14.4 \pm 2.1$ & $2.0 \pm 0.7$ & $2.9 \pm 0.6$ & $48.3 \pm 7.2$ \\
\hline $\mathrm{Te}$ & $0.33 \pm 0.09$ & $0.17 \pm 0.04$ & $0.20 \pm 0.09$ & $0.05 \pm 0.02$ & $1.2 \pm 0.2$ & $0.40 \pm 0.12$ \\
\hline $\mathrm{Ti}$ & $9.9 \pm 2.1$ & $3.5 \pm 0.9$ & $3.6 \pm 2.1$ & $35.6 \pm 1.9$ & $37.1 \pm 0.7$ & $105 \pm 11$ \\
\hline $\mathrm{U}$ & $<0.005$ & $<0.005$ & $<0.005$ & $<0.005$ & $<0.005$ & $0.79 \pm 0.12$ \\
\hline W & $<0.005$ & $<0.005$ & $<0.005$ & $0.07 \pm 0.03$ & $<0.005$ & $<0.005$ \\
\hline $\mathrm{Zn}$ & $120 \pm 58$ & $21 \pm 10$ & $16.5 \pm 1.8$ & $108 \pm 10$ & $235 \pm 32$ & $205 \pm 31$ \\
\hline $\mathrm{Zr}$ & $4.7 \pm 1.7$ & $2.5 \pm 0.6$ & $2.4 \pm 0.7$ & $5.5 \pm 1.1$ & $17.6 \pm 3.6$ & $10.8 \pm 2.2$ \\
\hline El. & 3004.KAB & 3005.KAB & 3006.KAB & 3007.KAB & 3008.KAB & 3009.KAB \\
\hline $\mathrm{Au}[\%]$ & $98.86 \pm 0.14$ & $98.84 \pm 0.09$ & $99.05 \pm 0.07$ & $99.19 \pm 0.50$ & $98.85 \pm 0.88$ & $99.42 \pm 0.40$ \\
\hline $\mathrm{Ag}[\%]$ & $0.30 \pm 0.06$ & $0.65 \pm 0.12$ & $0.34 \pm 0.05$ & \begin{tabular}{|l|}
$0.54 \pm 0.05$ \\
\end{tabular} & $0.82 \pm 0.19$ & $0.13 \pm 0.04$ \\
\hline $\mathrm{Cu}[\%]$ & $0.14 \pm 0.02$ & $0.046 \pm 0.005$ & $0.04 \pm 0.01$ & $0.025 \pm 0.003$ & $0.23 \pm 0.04$ & $0.030 \pm 0.008$ \\
\hline As & $32.9 \pm 4.9$ & $113 \pm 11.3$ & $62.6 \pm 24.3$ & $36.9 \pm 8.9$ & $36 \pm 14$ & $55 \pm 15$ \\
\hline $\mathrm{Bi}$ & $<0.003$ & $0.69 \pm 0.21$ & $<0.003$ & $<0.003$ & $<0.003$ & $0.7 \pm 0.3$ \\
\hline $\mathrm{Cd}$ & $0.073 \pm 0.038$ & $0.74 \pm 0.18$ & $0.10 \pm 0.04$ & $1.02 \pm 0.19$ & $1.0 \pm 0.4$ & $0.8 \pm 0.3$ \\
\hline Co & $0.30 \pm 0.08$ & $1.90 \pm 0.48$ & $0.8 \pm 0.1$ & $0.63 \pm 0.09$ & $0.35 \pm 0.12$ & $0.8 \pm 0.2$ \\
\hline $\mathrm{Fe}$ & $343 \pm 37$ & $2120 \pm 680$ & $1084 \pm 68$ & $1041 \pm 98$ & $280 \pm 123$ & $1790 \pm 226$ \\
\hline $\mathrm{Ga}$ & $<0.004$ & $2.3 \pm 0.6$ & $0.40 \pm 0.05$ & $<0.004$ & $<0.004$ & $1.1 \pm 0.5$ \\
\hline In & $0.60 \pm 0.25$ & $0.033 \pm 0.015$ & $<0.003$ & $<0.003$ & $0.10 \pm 0.04$ & $0.20 \pm 0.08$ \\
\hline Ir & $0.70 \pm 0.08$ & $0.7 \pm 0.2$ & $0.87 \pm 0.17$ & $0.40 \pm 0.12$ & $0.23 \pm 0.08$ & $0.19 \pm 0.08$ \\
\hline $\mathrm{Mn}$ & $23.4 \pm 4.4$ & $508 \pm 53$ & $99 \pm 29$ & $47 \pm 20$ & $37 \pm 13$ & $25 \pm 7$ \\
\hline Mo & $0.037 \pm 0.017$ & $0.29 \pm 0.11$ & $0.020 \pm 0.008$ & $0.040 \pm 0.008$ & $0.45 \pm 0.08$ & $0.09 \pm 0.03$ \\
\hline $\mathrm{Ni}$ & $2.5 \pm 0.9$ & $3.8 \pm 1.2$ & $6.5 \pm 2.5$ & $1.1 \pm 0.3$ & $1.37 \pm 0.42$ & $3.2 \pm 0.9$ \\
\hline $\mathrm{Pb}$ & $123 \pm 22$ & $48.1 \pm 10.6$ & $15.7 \pm 6.2$ & $1.37 \pm 0.18$ & $4.2 \pm 1.1$ & $13.9 \pm 2.6$ \\
\hline $\mathrm{Pd}$ & $95.2 \pm 6.4$ & $15.4 \pm 3.1$ & $40 \pm 17$ & $54.6 \pm 4.6$ & $42.3 \pm 20.9$ & $29 \pm 12$ \\
\hline $\mathrm{Pt}$ & $125 \pm 16$ & $90 \pm 16$ & $62.7 \pm 12.4$ & $63.4 \pm 9.5$ & $73 \pm 29$ & $43 \pm 21$ \\
\hline
\end{tabular}




\begin{tabular}{|l|l|l|l|l|l|l|}
\hline Re & $(17 \pm 7) .10^{-4}$ & $<0.001$ & $(25 \pm 12) .10^{-4}$ & $<0.001$ & $<0.001$ & $<0.001$ \\
\hline $\mathrm{Rh}$ & $0.10 \pm 0.01$ & $0.27 \pm 0.03$ & $0.18 \pm 0.06$ & $0.14 \pm 0.05$ & $0.065 \pm 0.027$ & $0.08 \pm 0.03$ \\
\hline $\mathrm{Ru}$ & $0.043 \pm 0.009$ & $0.14 \pm 0.03$ & $0.13 \pm 0.02$ & $0.022 \pm 0.003$ & $0.09 \pm 0.04$ & $0.003 \pm 0.002$ \\
\hline $\mathrm{Sb}$ & $0.17 \pm 0.06$ & $0.42 \pm 0.09$ & $<0.003$ & $<0.003$ & $0.023 \pm 0.007$ & $0.20 \pm 0.05$ \\
\hline $\mathrm{Se}$ & $<0.3$ & $<0.3$ & $<0.3$ & $<0.3$ & $<0.3$ & $<0.3$ \\
\hline $\mathrm{Sn}$ & $14.6 \pm 2.7$ & $41.5 \pm 6.2$ & $11.2 \pm 1.2$ & $3.2 \pm 0.5$ & $264 \pm 88$ & $18.8 \pm 5.5$ \\
\hline $\mathrm{Te}$ & $0.16 \pm 0.05$ & $0.36 \pm 0.11$ & $0.57 \pm 0.18$ & $0.17 \pm 0.06$ & $0.093 \pm 0.025$ & $0.42 \pm 0.18$ \\
\hline $\mathrm{Ti}$ & $0.9 \pm 0.3$ & $156 \pm 16$ & $36 \pm 14$ & $6.9 \pm 2.9$ & $4.9 \pm 2.4$ & $17.5 \pm 3.7$ \\
\hline $\mathrm{U}$ & $<0.005$ & $5.1 \pm 0.5$ & $0.097 \pm 0.015$ & $0.037 \pm 0.005$ & $<0.005$ & $1.8 \pm 0.6$ \\
\hline $\mathrm{W}$ & $<0.005$ & $0.007 \pm 0.003$ & $0.057 \pm 0.022$ & $<0.005$ & $0.013 \pm 0.006$ & $0.010 \pm 0.007$ \\
\hline $\mathrm{Zn}$ & $93.9 \pm 16.3$ & $217 \pm 22$ & $97 \pm 39$ & $39.8 \pm 8.0$ & $248 \pm 109$ & $171 \pm 72$ \\
\hline $\mathrm{Zr}$ & $1.5 \pm 0.5$ & $10.1 \pm 2.1$ & $5.3 \pm 1.7$ & $2.1 \pm 0.9$ & $2.7 \pm 2.5$ & $5.1 \pm 5.9$ \\
\hline
\end{tabular}

Table 3: Elemental composition of the analyzed gold samples $\left(\mathrm{mg} \mathrm{kg}^{-1}\right)$ from the grave funeral-pile from the ancient town of Kabyle

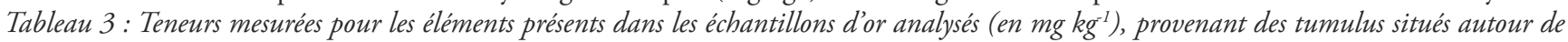
la ville ancienne de Kabyle.

Unfortunately, at this stage of investigation it is impossible to identify the sources of gold used for the preparation of the golden wreath and the other golden objects found in the pyregrave in the tumulus of Kabyle due to the lack of analytical data for the concentrations of platinum group elements in different gold sources in Bulgaria. Using only this list of elements it is very difficult to determine the source of gold used be ancient goldsmiths (see also Pernicka, 2013). The possible origin of the golden wreath from North Aegean might be presumed having in mind that the deceased was an officer of the Macedon garrison of Kabyle, and considering the discovered golden stater of Philipp II given to the dead man as a Charon's obolus, as well as the imported pottery from South and the Thracian amphorae (for details see Stoyanov et al., 2013).

\section{Conclusion}

Using ICP-AES and ICP-MS samples from the golden wreath found in the tumulus of Kabyle were analyzed. Results indicate that the wreath was produced using very high refined gold alloy (Au between 97.1 and 99.9\%).

Comparosin to other gold finds is difficult, because of the lack of literature data. In most of the investigations from the same period the gold objects are found in differerent parts of Europe and Asia (see Gondonneau et al., 2001; Guerra, 2004; 2005; Guerra and Calligaro, 2007; Guerra et al., 2008; Hall et al., 1998; Hauptmann et al., 2010; Iliev, 2006; Kuleff et al., 2009; Pantazis et al., 2003). Recently, archaeometric investigation of gold objects from the same period found in Bulgaria is described in Todorov et al., 2015.
However it could be assumed that the gold objects investigated in this study are produced from very pure gold, obtain through the process of purification. Alas, it is currently not possible to identify the gold sources used by the ancient goldsmiths. The study provides analytical data to be used for comparison with other archaeological finds and is a good basis for future research.

\section{Acknowledgements}

This study was carried out with the financial support of the Scientific Investigations Fund of the Bulgarian Ministry of Education and Science under the contract No DO 02/60/03.12.2008.

\section{References}

Boyle R. W., 1987. Gold - History and Genesis of Deposits, Van Nostrand Reinhold.

Cojocaru V., Badica T., Popescu I.V., 2003. Natural gold composition studied by proton activation analysis. Romanian Reports in Physics, 55: 460-463.

Domaradski M., Taneva V., 1998. Thracian culture in the transition to the Hellenistic period, Emporion Pistiros, II, "Belloprint" Publishing House Ltd., Pazardzhik, Bulgaria (in Bulg.).

Donder H., 1980. Zaumzeug in Griecheland und Cypern. In: Prähistorische Bronzefunde, PBF Abt. XVI, 3, Beck, Munich.

Dube R. K., 2006. Interrelation between gold and tin: A historical perspective, Gold Bulletin, 39(3): 103-113.

Getov L., Cohors I., 2003. Athoitorun in Kabyle. Thracia 15 (Studia in honorem annorum LXX Alexandri Fol), 121-123. 
Gondonneau A., Guerra M.F., Cowell M.R., 2001. Searching for the Provenance of gold. The methodology of gold analysis by ICP-MS: first developments. Proc. of Archaeometry' 2000: CD-ROM, University of Mexico.

Guerra M.F., 2004. Fingerprinting ancient gold with proton beams of different energies. Nuclear instruments and methods in physics research, Section B, 226: 185-198.

Guerra M.F., 2005. Trace elements fingerprinting using accelerators and ICP-MS: circulation of gold from the 6th century $B C$ to the 12th century AD. In: R. Van Grieken, K. Janssens (Eds.). Cultural heritage conservation and environmental impact assessment by nondestructive testing and micro-analysis, Balkema, Leiden, 223-244.

Guerra M.F., Calligaro T., 2007. The treasure of Guarrazar: Tracing the gold auplies in the Visgothic Iberian peninsula. Archaeometry, 49: 53-74.

Guerra M.F., Radtke M., Reiche I., Riesemeier H., Strub E., 2008. Analysis of trace elements in gold alloys by SR-XRF and high energy at the BAM line. Nuclear instruments and methods in physics research, Section B, 266: 2334-2338.

Hall M.A., Brimmer S.P., Li F. H., Yablonski L., 1998. ICP-MS and ICP-AES studies of gold from a late Sarmatian burial. Journal of Archaological Science, 25: 545-552.

Hauptmann -A., Bendall Ch., Brey G., Japariże I., Gambaschidze I., Klein S., Prange M., Stollner M., 2010. Gold in Georgien. Analytische Untersuchungen an Goldartefakten und an Naturgold aus dem Kaukasus und dem Transkaukasus, In Von Majkop bis Trialeti Gewinnung und Verbreitung von Metallen und Obsidian in Kaukasien im 4.-2. Jt. v. Chr. Beitrage des Internationalen Symposiums in Berlin vom 1.-3. Juni 2006, S. Hansen, A. Hauptmann, I. Motzenbacker, E.Pernicka (eds), Dr. Rudolf Habelt GmbH, Bonn.

ILIEV I., 2006. Archaeometric investigations of metal finds from Bulgaria using INAA, ED-XRF and ICP-MS, PhD thesis, University of Sofia "St. Kliment Ohridski”, Sofia, Bulgaria (in Bulg.).

Junk S.A., Pernicka E., 2003. An assessment of osmium isotope ratios as a new tool to determine the provenance of gold with platinum-group metal inclusions. Archaeometry, 45: 313-331.

Kovachev V., Stefanova V., Nedialkov R., Mladenov V., 2007. Eluvial-alluvial gold from the gold-copper occurrence Borov Dol (R. Macedonia). Part I: Geochemistry of stream sediments and their relation to the source rocks and ores. Review of Bulgarian Geological Society. 6: 66-76.

Kuleff I., 2012. Archaeometry, "St. Kliment Ohridski” University Publishing House, Sofia.

Kuleff I., Tonkova M., Stoyanov T. 2009. Chemical composition of gold breast plates from ancient Thrace $\left(5^{\text {th }}-4^{\text {th }}\right.$ century BC). Archaeologia Bulgarica, XIII: 11-20.

Pantazis T., Karydas A. G., Doumas Chr.,Vlachopoulos A., Nomikos P., Dinsmore M., 2003. X-Ray Fluorescence Analysis of a Gold Ibex and other Artifacts from Akrotiri, Proc. of the 9th International Aegean Conf. - Metron, Measuring the Aegean Bronze Age, New Haven, Yale University, 18-21 April 2002, K. P. Foster and R. Laffineur (eds.), Université de Liège, Histoire de l'art et archéologie de la Grèce antique, 159-163.

Pernicka E., 2013. Possibilities and limitations of provenance studies of ancient silver and gold. In: Metalle der Macht - Frühes Gold und Silber; Metals of Power - Early Gold and Silver. 6. Mitteldeutschen Archäologentag vom 17. bis 19. Oktober 2013 in Halle (Saale), 1: 153-164. Pohl, W., 1992. W. \& W.E. Petrascheck's Lagerstättenlehre. 4. Auflage. E. Schweizerbart'sche Verlagsbuchhandlung (Nägele und Obermiller), Stuttgart 1992, S. 193. ISBN 3-510-65150-2.

Popov Hr., 2002. Urbanization in inland areas of Thrace and Iliria during $6^{\text {th }}-1^{\text {st }}$ centuries BC. PhD thesis, University of Sofia "St. Kliment Ohridski”, Sofia, Bulgaria (in Bulg.).

Ramage A., Craddock P.T., 2000. King Croesus' Gold: Excavations at Sardis and the History of Gold Refining, Harvard University Art Museums, in association with British Museum Press, ISBN 9780674503700.

Schlosser S., Kovacs R., Pernicka E., Günter D., Tellenbach M., 2009. Fingerprints of gold. In M. Reindel, G. Wagner (Eds.) New technologies for archaeology multidisciplinary investigations in Palpa and Nasca, Peru, Springer Verlag, Berlin, Heidelberg, 409-436.

Stefanova V., Kovachev V., Mladenov V., Stanimirova Tz., 2007. Eluvial-alluvial gold from the gold-copper occurrence Borov Dol (R. Macedonia). Part II: Mineralogy of gold and stream sediments, Review of Bulgarian Geological Society. 6: 77-91.

Stoyanov T., Mikov R., Dzhanfezova T., 2013. Early Hellenistic tumulus near the village of Kabyle, Yambol district, Bulgarian e-Journal of Archaeology, 3 (2), 246-314 (in Bulg.)

Stoyanov T., Mikov R., Dzhanfezova T., 2010. Rescue archaeological survey of Area 7 - mound and its surrounding space, and drilling along the Kabyle-Jelyo Voivoda village road. In: D. Gergova et al., (Eds.) Archaeological discoveries and excavations in 2009, Sofia, p. 239-243 (in Bulg.).

Todorov B., Mihaylova V., Gergova D., Kuleff I., 2015. The results of ED-XRF analyses of the golden treasure from the royal necropolis of Dausdava-Helis the Great Svestari tumulus (The Sboryanovo National Reserve, NE Bulgaria), Archaeologia Bulgarica (in press).

Vasilescu A., Constantinescu B., Bugoi R., 2011. Micro-SRXRF studies if gold provenance in archaeology. Romanian Reports in Physics, 3-4: 366-372.

Velkov V., Kabyle. 1990. Eine Hellenistische Stadt in Thrakien. In Akten des XIII Internationalen Kongress für Klassische Archäologie, P. von Zabern, Berlin'1988, Mainz am Rhein, 606-607. 


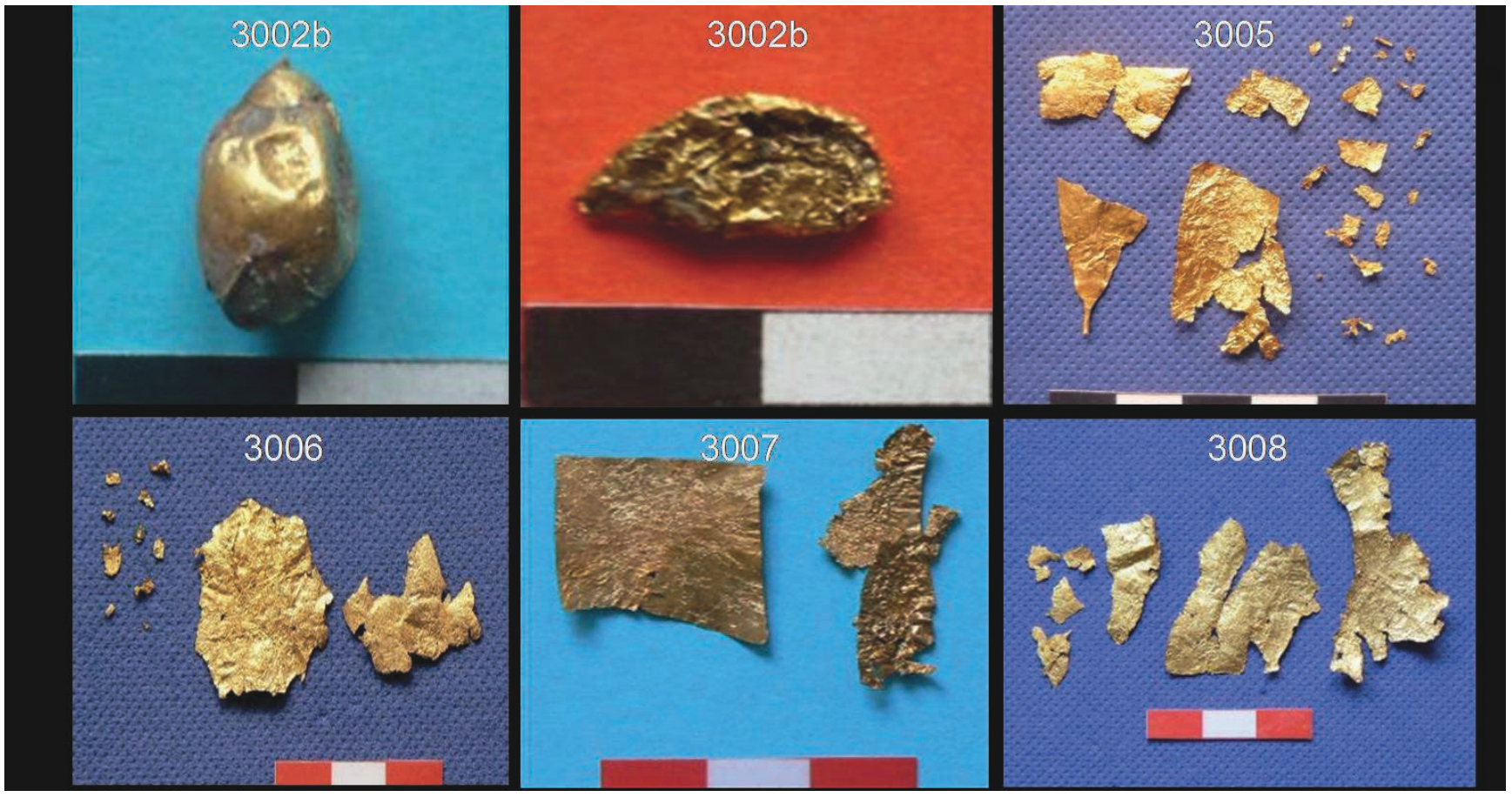

Figure 4 : Deyan Lesigyarski et al., Thracian Golden Wreath from Kabyle, Bulgaria: Chemical Composition (p. 151)

Figure 3 : Olivier BuchsensCHUTZ et al., Une base pour l'élaboration de modèles de peuplement de l'Âge du Fer en France (p. 163)

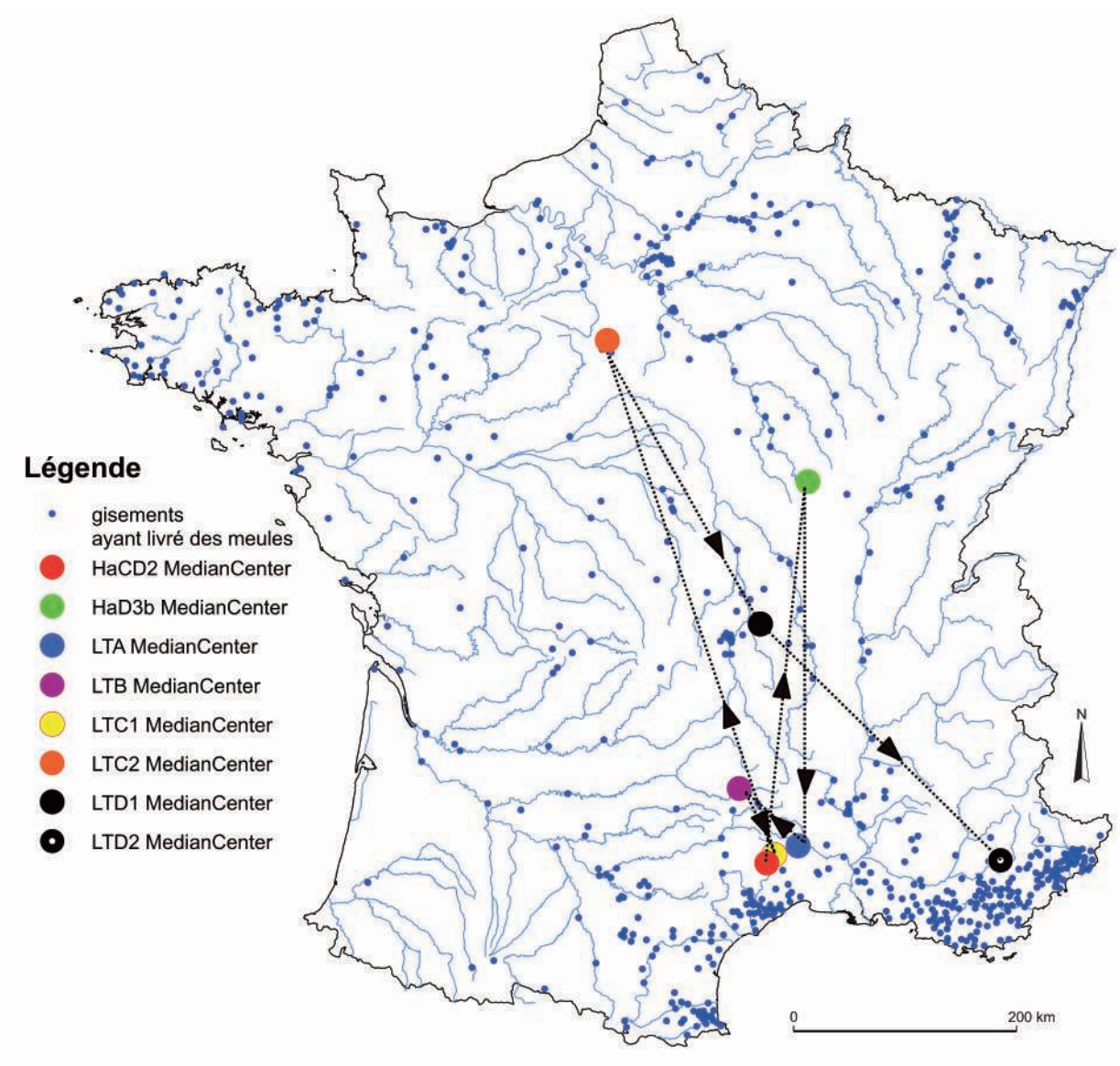

Evolution chronologique du centre médian de la répartition des meules 